\title{
Risk Management of Time Overrun in Multiple Phases of Construction: Consultant Perspective
}

\author{
Anastasia Erlita', Mawardi Amin², Bambang Purwoko Kusumo Bintoro ${ }^{3}$ \\ ${ }^{1}$ Master of Civil Engineering Department, Universitas Mercu Buana, Jakarta 11650 Indonesia \\ ${ }^{2}$ Master of Civil Engineering Department, Universitas Mercu Buana, Jakarta 11650 Indonesia \\ ${ }^{3}$ Master of Management Program Study, Universitas Bakrie, Jakarta 12920, Indonesia
}

Corresponding Author: Anastasia Erlita

\begin{abstract}
This article reports a study on the construction of a food factory building in Indonesia by investigating the root causes of time overruns from the perspective of a consultant. Although many risks have been identified at various stages of the construction project, it is not clear which risk is the main cause of project delays. To better understand the optimization of risk management and risk mitigation, a multi-stage risk management is proposed, which is divided into four phases: pre-design, design, project bidding, and construction. Therefore, the use of bow tie analysis allows for more in-depth inspections to identify risks. From each bow tie diagram, a detailed risk mitigation table can be developed, and it is easier to plan the response to each risk. From this research, the top 5 reasons for the delay of the project were found. The first reason for the delay is X3a2, which has a value of 4.578 , which is a change in design idea. The second value of $\mathrm{X} 3 \mathrm{c} 1$ is 4.533 , which is the technical data of new machines appearing. The third row is $\mathrm{X} 2 \mathrm{~b} 4$, the value is 4.467 , waiting for owner's decision. The fourth place is the variable X1b3 Machine technical data appears after tender, with a value of 4.422 , and the fifth place is the difference between local regulations and foreign regulations, with a value of 4.378 .
\end{abstract}

Keywords: factory building, risk management, time overrun.

\section{INTRODUCTION}

Time overruns will affect work interruptions, low productivity, project delays, cost increases, third party claims and contract terminations. It refers to a long construction period due to problems that occurred during project implementation (Kikwasi, 2012). Unfortunately, project delays are a common risk and occur in almost all projects in Indonesia (Le Hoai et al., 2008) even though the supervisory function has been carried out properly. Susetyo, B. and Utami, T. (2017) stated that a project is considered successful if it meets the quality, cost and time targets.

Sudirman, W. B. and Hardjomuljadi, S. (2011) stated that project management can be defined as the application of knowledge, skills, tools, and techniques to complete projects in order to meet their requirements. Based on PMBOK Edition 6, the project management process consists of 5 process stages: initiation, planning, implementation, monitoring \& control, and closure, but in this study we will focus on the initiation, planning, and implementation phases, as well as elaborating various risks. which can arise by identifying, measuring, mapping, developing alternative risk management, monitoring risks, and controlling risk management or prevention with a risk management system. Risk Management in the construction sector is very important to achieve project objectives (time, cost, quality and safety), the risk management system helps project managers in prioritizing resource allocation and also helps them in making more reliable decisions, thereby contributing to project success and achievement of objectives. This 
study elaborates the time overrun risk management. The object chosen is an 8storey flour factory building located in an industrial area in Indonesia. This building is used as an object of research because of its high complexity, and risk management research can be carried out on a time overrun basis at all stages according to the research objectives, because all stages in this project have a time overrun.

\section{RESEARCH PROBLEM AND OBJECTIVES}

There are two main research problem: 1) How can the impact of risk factors cause the delay and how big the impact on the project? 2) How is risk handled? The research objectives are to analyse the impact of risk factors causing the delay and assess how big the impact is on the project. For research objectives to be achieved, it is necessary to make limitations that are adjusted to the research topic, given the wide scope of discussion in this project, namely regarding the delays that occur in each phase of the project from the point of view of the planning consultant. From the 5 phases of project management according to PMBOK 6th edition (initiating, planning, executing, monitoring \& controlling, and closing), this research is limited to the initiating to executing phase which includes: pre-design phase, planning phase, tender phase, and construction phase.

\section{LITERATURE REVIEW Time Overrun}

In research by Pai \& Bharath (2013), time overrun is defined as slowing down work without stopping it altogether. Time overruns will result in work interruptions, low productivity, project delays, cost increases, third party claims, and termination of contracts. It refers to a long construction period due to problems that occurred during project implementation (Kikwasi, 2012). Lo, Fung \& Tung (2006) and Assaf \& Al-Hejji (2006) mention delay as the time that exceeds the contract date or exceeds the agreed date of the parties to complete the project. According to (Hasan, Suliman, and Malki, 2014), time overrun can be interpreted as a delay in project completion due to predictable and unpredictable reasons.

\section{Type of Delay}

There are two types of delays, namely unforgivable delays and forgivable delays (Tumi, Omran and Pakir, 2009; Hamzah et al., 2011; Ibironke et al., 2013). Unforgivable delays are delays caused by the contractor or its suppliers, through no fault of the owner. For example: difficulties in project financing by contractors, poor site management and supervision by contractors, poor communication, and coordination by contractors with other parties, and inadequate planning and scheduling (Hamzah et al., 2011). Meanwhile, forgivable delays are divided into two, namely compensated delays and noncompensable delays. Delays also affect costs; therefore, time overrun risk management must be applied to each construction.

\section{Risk management}

In accordance with the construction management expert training module by Umum (2007), there are 4 stages in risk management. The first stage is project risk identification, the second stage is project risk analysis which is divided into qualitative and quantitative analysis, the third stage is risk management output in the form of risk management strategies, and the last stage is risk monitoring and auditing to recommend risk prevention and mitigation actions.

\section{MATERIALS \& METHODS}

This research begins by creating a research gap to find research methods and objects. After that, the research title was obtained for further research purposes, the formulation of the problem and the limitations of the research. Then, the research instruments are arranged in the form of variables collected through pilot 
surveys, primary data collection such as minutes of meetings, pictures, sequence variations, location memos, planning schedules, implementation schedules, revisions to implementation schedules, project budgeting, and others. Data that can be used as a reference in analyzing the factors. Then secondary data collection was done in the form of literature study.

After that, the collected variables were analysed for cause and effect using a bow-tie diagram, and then conducted a questionnaire to find rankings with RII. The final step of the research is to formulate solutions and prevent risks in the most impactful phase.

\section{Surveys and Questionnaires}

The questionnaire was made based on the variables collected from the literature review conducted by the author and the variables were collected through a pilot survey. The author conducted interviews with 5 experts who worked on consultants to assess the suitability of the variables in previous studies so that they could be the basis for research in the case studies that the authors took. The selected experts all work in consultants and know in detail about the project in the selected case study.

Furthermore, the obtained variables will be combined with other additional variables obtained from the pilot survey to obtain predictive variables that will be the basis before carrying out the analysis using the Bow-Tie Analysis method to look for causes and effects (Cause and Consequences) on the 4 phases which the authors classify as main variable. A total of 45 questionnaires have been given to experts as well as other parties who participated in the design \& construction of the Flour Mill project. The main variable in this study is the construction stage which consists of the pre-design stage $(\mathrm{Xa})$, the design stage $(\mathrm{Xb})$, the tender stage $(\mathrm{Xc})$ and the construction stage (Xd). Primary and secondary data collection is also needed to classify sub-variables for each main variable.

A total of 45 major risks were identified in this study. 20 risks adopted from Gunduz et al. (2013), and other risks were identified from expert input through a pilot survey. Data collection in this study was carried out when the construction progress reached $90 \%$ and neared project completion. The construction time started from August 2019 and underwent several revisions to the time schedule due to time overruns.

The questionnaire survey was conducted online to 58 respondents using a google form. In the survey conducted, the number of questionnaires returned was 45 respondents, while the other 13 results could not be used as research data because they were incomplete, so they did not meet the requirements.

The distribution of the survey was carried out evenly to all parties responsible for this project, with varying work experiences. A total of $11 \%$ of respondents had $0-5$ years of experience, $31 \%$ of $6-10$ years of experience, $31 \%$ of $11-17$ years of experience and $27 \%$ of 20 years of experience.

The variables used in this study can be seen in Table 1.

Table 1. Research Variable

\begin{tabular}{|l|l|l|l|l|l|l|}
\hline Var & Phase & No. & Var & Main Factor & Var & Sub Factor \\
\hline Xa & \multirow{4}{*}{ Pre-Design } & $\mathbf{1}$ & X1a & Building Permit & X1a1 & Building permit data is different from site conditions \\
\cline { 3 - 7 } & $\mathbf{2}$ & & & X1a2 & Lack of open spaces on site \\
\cline { 3 - 7 } & $\mathbf{3}$ & & & X1a3 & Changes in development regulations \\
\cline { 3 - 7 } & $\mathbf{4}$ & X2a & Owner & X2a1 & Issuance of Purchase Order and Late progress payments \\
\cline { 3 - 7 } & $\mathbf{5}$ & & & X2a2 & In-depth feasibility study \\
\hline & $\mathbf{6}$ & X3a & Supporting Data & X3a1 & Incomplete As Built Drawing \\
\hline & $\mathbf{7}$ & & & X3a2 & Design idea changes \\
\cline { 3 - 6 } & $\mathbf{8}$ & X4a & Coordination & X4a1 & Consultant presentation \\
\hline & $\mathbf{9}$ & & & X4a2 & $\begin{array}{l}\text { The process of tendering and the implementation of new } \\
\text { site }\end{array}$ \\
\hline
\end{tabular}


Anastasia Erlita et.al. Risk management of time overrun in multiple phases of construction: consultant perspective.

\begin{tabular}{|c|c|c|c|c|c|c|}
\hline \multicolumn{7}{|c|}{ Table 1 Continued... } \\
\hline \multirow[t]{14}{*}{$\mathbf{X b}$} & \multirow[t]{14}{*}{ Design } & 10 & $\mathrm{X} 1 \mathrm{~b}$ & Consultant & X1b1 & Differences in idealism with foreign consultants \\
\hline & & 11 & & & $\mathrm{X} 1 \mathrm{~b} 2$ & Design Errors \\
\hline & & 12 & & & X1b3 & The machine plan has not been fixed \\
\hline & & 13 & & & $\mathrm{X} 1 \mathrm{~b} 4$ & Delay in production of drawings \& tender documents \\
\hline & & 14 & $\mathrm{X} 2 \mathrm{~b}$ & Owner & $\mathrm{X} 2 \mathrm{~b} 1$ & Late progress payment from owner \\
\hline & & 15 & & & $\mathrm{X} 2 \mathrm{~b} 2$ & Late of design approval from owner \\
\hline & & 16 & & & $\mathrm{X} 2 \mathrm{~b} 3$ & Changes from owner \\
\hline & & 17 & & & $\mathrm{X} 2 \mathrm{~b} 4$ & Waiting for owner's decision \\
\hline & & 18 & $\mathrm{X} 3 \mathrm{~b}$ & Coordination & $\mathrm{X} 3 \mathrm{~b} 1$ & Coordination meetings between consultants \\
\hline & & 19 & & & $\mathrm{X} 3 \mathrm{~b} 2$ & Poor communication and coordination with other parties \\
\hline & & 20 & $\mathrm{X} 4 \mathrm{~b}$ & Software & $\mathrm{X} 4 \mathrm{~b} 1$ & Drawing Information is in PDF format \\
\hline & & 21 & & & $\mathrm{X} 4 \mathrm{~b} 2$ & Use of different software \\
\hline & & 22 & $\mathrm{X} 5 \mathrm{~b}$ & Regulatory Standards & X5b1 & Differences between local and foreign regulations \\
\hline & & 23 & X6b & Scope of work & X6b1 & Unclear scope of work \\
\hline \multirow[t]{6}{*}{$\mathbf{X c}$} & \multirow[t]{6}{*}{ Tender } & 24 & $\mathrm{X} 1 \mathrm{c}$ & Schedule & $\mathrm{X} 1 \mathrm{c} 1$ & Determination of the long tender schedule \\
\hline & & 25 & & & $\mathrm{X} 1 \mathrm{c} 2$ & Many stages of clarification \\
\hline & & 26 & $\mathrm{X} 2 \mathrm{c}$ & Tender Documents & $\mathrm{X} 2 \mathrm{c} 1$ & Post-meeting design revision \\
\hline & & 27 & & & $\mathrm{X} 2 \mathrm{c} 2$ & Design Changes \\
\hline & & 28 & $\mathrm{X} 3 \mathrm{c}$ & Supporting data & $\mathrm{X} 3 \mathrm{c} 1$ & Machine technical data appears after tender \\
\hline & & 29 & & & $\mathrm{X} 3 \mathrm{c} 2$ & Tenders are carried out separately per scope of work \\
\hline \multirow[t]{16}{*}{ Xd } & \multirow{16}{*}{ Construction } & 30 & X1d & External & X1d1 & Weather factors \\
\hline & & 31 & & & $\mathrm{X} 1 \mathrm{~d} 2$ & Soil conditions \\
\hline & & 32 & & & $\mathrm{X} 1 \mathrm{~d} 3$ & Late delivery of imported materials / machinery \\
\hline & & 33 & & & $\mathrm{X} 1 \mathrm{~d} 4$ & Regional regulations \\
\hline & & 34 & $\mathrm{X} 2 \mathrm{~d}$ & Owner & $\mathrm{X} 2 \mathrm{~d} 1$ & Owner request \\
\hline & & 35 & & & $\mathrm{X} 2 \mathrm{~d} 2$ & Decision Making \\
\hline & & 36 & & & $\mathrm{X} 2 \mathrm{~d} 3$ & Variation Order Price \\
\hline & & 37 & $\mathrm{X} 3 \mathrm{~d}$ & Implementation & $\mathrm{X} 3 \mathrm{~d} 1$ & Additional work due to damage of existing buildings \\
\hline & & 38 & & & $\mathrm{X} 3 \mathrm{~d} 2$ & Unfinished work. \\
\hline & & 39 & & & $\mathrm{X} 3 \mathrm{~d} 3$ & Unclear scope of work \\
\hline & & 40 & $\mathrm{X} 4 \mathrm{~d}$ & Project Resources & $\mathrm{X} 4 \mathrm{~d} 1$ & Number of workers \\
\hline & & 41 & & & $\mathrm{X} 4 \mathrm{~d} 2$ & Material delivery \\
\hline & & 42 & & & $\mathrm{X} 4 \mathrm{~d} 3$ & Heavy equipment damage \\
\hline & & 43 & $\mathrm{X} 5 \mathrm{~d}$ & Design & X5d1 & Machine design changes \\
\hline & & 44 & & & $\mathrm{X} 5 \mathrm{~d} 2$ & Design changes during construction \\
\hline & & 45 & & & $\mathrm{X} 5 \mathrm{~d} 3$ & Differences in structure, architecture, and ME drawings \\
\hline
\end{tabular}

\section{Statistical Analysis}

The results of the validity test were carried out with SPSS software. With the validity test, it is believed that each question in this questionnaire provides valid results with the provisions of $\mathrm{r}$ Count $>\mathrm{r}$ Table. SPSS test results obtained r Count> 0.294 which means all factors are valid. The results of the reliability test on all the variables tested in this study stated that Cronbach's alpha was higher than the baseline value, namely $0.944>0.60$. These results prove that all of the variable statements tested on the questionnaire are reliable.

Hypothesis testing using multinomial regression coefficient test, which is used to determine whether the independent variables ( $\mathrm{Xa}, \mathrm{Xb}, \mathrm{Xc}$ and $\mathrm{Xd}$ ) in this study have a significant effect on the dependent variable (Y). There are 4 hypotheses in this study. (H1: Xa affects $\mathrm{Y}$, $\mathrm{H} 2$ : Xb affects Y, H3: Xc affects Y and H4:
Xd affects Y). The results of the multinomial regression test resulted in sig < (0.05). The $\mathrm{p}$-value for $\mathrm{H} 1$ is 0.000 , the $\mathrm{p}$ value for $\mathrm{H} 2$ is 0.001 , the $\mathrm{p}$-value for $\mathrm{H} 3$ is 0.018 and $\mathrm{H} 4$ is 0.001 where the four statements are $<\alpha(0.05)$ so that all statements $\mathrm{H} 1, \mathrm{H} 2, \mathrm{H} 3$ and $\mathrm{H} 4$ are accepted.

\section{Bow-Tie Diagram}

Baddredine (2014) explains, The Bow-tie Analysis Method was developed by the Shell company to describe the overall accident scenario. This model has proven its efficiency in several real applications such as; risk management, risk analysis, risk assessment and implementation of preventive barriers. So this model can be used for various branches of risk management, including in the construction sector. Bow-tie method is a quantitative analysis used in this study. This method is an early stage in the analysis of variable data. The initial stage of making Bow-tie 

perspective.

Analysis is to determine the source of the problem. The next stage is to determine the initial event taken from the variables contained in Table 1, then look for the cause why the incident occurred, find ways to solve the problem, and analyze the consequences of the incident. In this study, a bow-tie model was created to see the sequence of events causing delays, starting from finding all the sources of problems in this project, looking for preventive steps from the source of the problem, and looking for steps to reduce them, impact of the risks that have occurred. Figure 1 is a bow-tie diagram. After pre-modelling the bow-tie diagram, each variable was reanalyzed, looked for prevention and treatment steps and made into a model diagram using BowTieXP software.

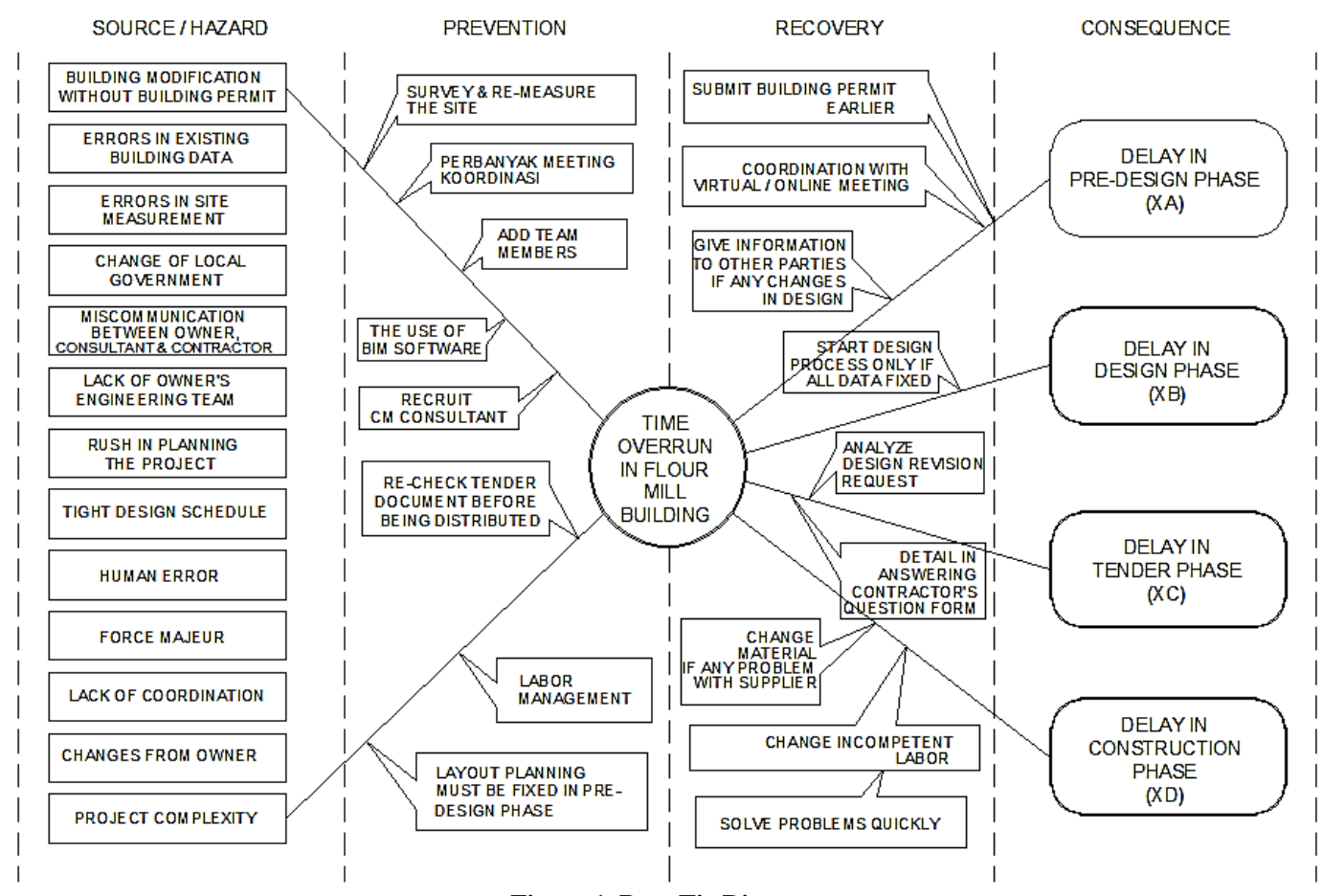

Figure 1. Bow-Tie Diagram

\section{RESULT}

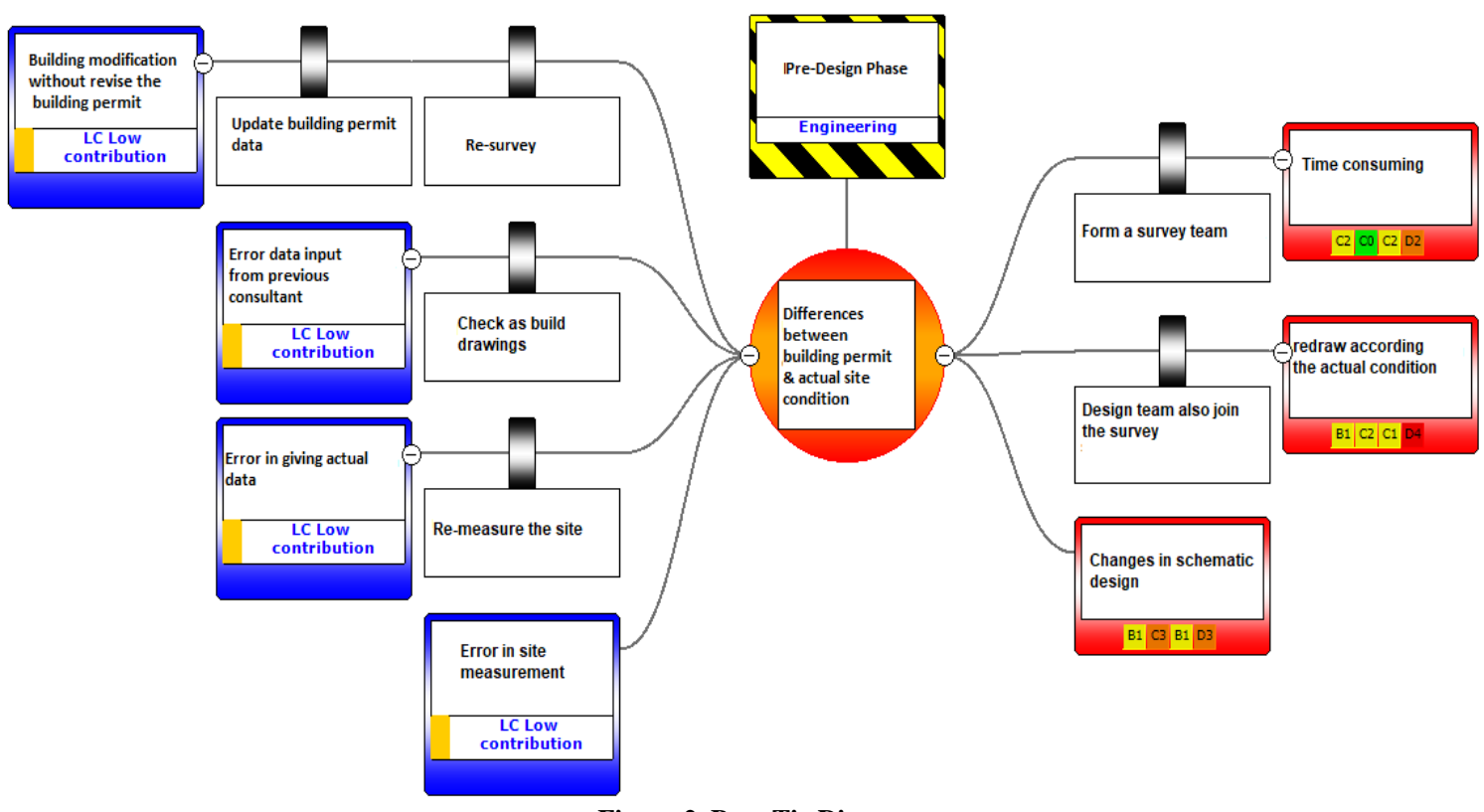

Figure 2. Bow-Tie Diagram 

perspective.

In this process, 45 bow-tie diagram models were obtained. Figure 2 is an example, in the pre-design phase there are 7 bowtie diagram models to see the initial causes and effects of each pre-designed variable. This X1a1 variable is the difference between the data of the existing building and the condition of the site. The reasons for the discrepancy were because the building had been modified without changing the IMB, errors in the IMB data entry from the previous consultant, errors in providing data from the owner, and measurement errors in the field.

While the consequences that arise from this variable are time consuming to conduct a re-survey to the site, redraw according to current conditions and changes to the design schematic drawings. The overall impact can be seen on the consequences/right side of the diagram. From each diagram that has been made, a risk mitigation table can be formulated by including prevention and risk management measures as can be seen in Table 2 below:

Table 2. Research Variable

\begin{tabular}{|c|c|c|c|c|c|c|c|}
\hline Var & Sub Factor & & Dampak Risiko & & $\begin{array}{l}\text { Langkah } \\
\text { Pencegahan }\end{array}$ & & Langkah Mengurangi \\
\hline \multirow[t]{2}{*}{ X1a1 } & $\begin{array}{l}\text { Differences } \\
\text { between building } \\
\text { permit \& actual } \\
\text { site condition }\end{array}$ & $\mathrm{o}$ & $\begin{array}{l}\text { Changes in schematic } \\
\text { drawings and zoning of } \\
\text { space requirements }\end{array}$ & o & $\begin{array}{l}\text { Re-survey the site } \\
\text { before conducting } \\
\text { preliminary design }\end{array}$ & o & $\begin{array}{l}\text { Revision of building permit } \\
\text { drawings according to field } \\
\text { conditions }\end{array}$ \\
\hline & & o & $\begin{array}{lll}\begin{array}{l}\text { Changes } \\
\text { calculation }\end{array} & \text { in } & \text { site } \\
\end{array}$ & & & & \\
\hline \multirow[t]{2}{*}{ X1a2 } & $\begin{array}{l}\text { Lack of open } \\
\text { spaces on site }\end{array}$ & $\mathrm{o}$ & $\begin{array}{l}\text { Constraints in managing } \\
\text { building permits }\end{array}$ & o & $\begin{array}{lr}\text { Purchase } & \text { of } \\
\text { additional } & \text { spaces } \\
\text { beside the site } & \end{array}$ & o & $\begin{array}{l}\text { The management of the } \\
\text { building permit is postponed } \\
\text { until the planning of the new } \\
\text { land begins }\end{array}$ \\
\hline & & o & $\begin{array}{lcr}\text { Lack of } & \text { space for } \\
\text { directors } & \text { of keet, } \\
\text { materials, } & \text { consulting } \\
\text { offices } & \end{array}$ & & & & \\
\hline \multirow[t]{2}{*}{$\mathbf{X 1 a 3}$} & $\begin{array}{l}\text { Changes } \\
\text { regulation }\end{array}$ & o & Design changes & o & $\begin{array}{l}\text { Sesrch and update for } \\
\text { latest regulation }\end{array}$ & o & $\begin{array}{l}\text { Detailed design postponed } \\
\text { until new regulation }\end{array}$ \\
\hline & & o & Building permit changes & & & & \\
\hline
\end{tabular}

\section{DISCUSSION}

\section{Relative Importance Index (RII)}

It was found the top 5 causes of delays in this project. The first rank that caused the delay was X3a2 with a value of 4,578 , namely changes in design ideas, the second rank was the variable $\mathrm{X} 3 \mathrm{c} 1$ with a value of 4,533, namely Machine technical data appears after tender. The third rank is $\mathrm{X} 2 \mathrm{~b} 4$ with a value of 4,467 , which is waiting for owner's decision. The fourth rank is variable X1b3 with an RII value of 4,422 and the fifth rank with an RII value of 4,378. RII can be seen in Table 3 .

Table 3. RII

\begin{tabular}{|l|l|l|l|}
\hline X3a2 & $\mathbf{4 . 5 7 8}$ & $\mathbf{1}$ & Design idea changes \\
\hline X3c1 & 4.533 & $\mathbf{2}$ & Machine technical data appears after tender \\
\hline X2b4 & 4.467 & $\mathbf{3}$ & Waiting for owner's decision \\
\hline $\mathbf{X 1 b 3}$ & 4.422 & $\mathbf{4}$ & The machine plan has not been fixed \\
\hline $\mathbf{X 5 b 1}$ & 4.378 & $\mathbf{5}$ & Differences between local and foreign regulations \\
\hline $\mathbf{X 2 b 2}$ & 4.333 & $\mathbf{6}$ & Late of design approval from owner \\
\hline $\mathbf{X 2 b 3}$ & 4.311 & $\mathbf{7}$ & Changes from owner \\
\hline $\mathbf{X 2 d 1}$ & 4.289 & $\mathbf{8}$ & Owner's request \\
\hline $\mathbf{X 5 d 1}$ & 4.178 & $\mathbf{9}$ & Changes in machine plan \\
\hline $\mathbf{X 2 c 1}$ & 4.133 & $\mathbf{1 0}$ & Post-meeting design revision \\
\hline $\mathbf{X 4 d 1}$ & 4.133 & $\mathbf{1 1}$ & Number of workers \\
\hline $\mathbf{X 4 b 2}$ & 4.111 & $\mathbf{1 2}$ & Use of different software \\
\hline $\mathbf{X 1 d 3}$ & 4.111 & $\mathbf{1 3}$ & Late delivery of imported materials / machinery \\
\hline $\mathbf{X 5 d 2}$ & 4.089 & $\mathbf{1 4}$ & Design changes during construction \\
\hline $\mathbf{X 1 b 2}$ & 4.067 & $\mathbf{1 5}$ & Design errors \\
\hline $\mathbf{X 5 d 3}$ & 4.044 & $\mathbf{1 6}$ & Unfixed design \\
\hline $\mathbf{X 1 d 1}$ & 4.022 & $\mathbf{1 7}$ & Weather condition \\
\hline
\end{tabular}


Anastasia Erlita et.al. Risk management of time overrun in multiple phases of construction: consultant perspective.

\begin{tabular}{|l|l|l|l|}
\hline \multicolumn{3}{|c|}{ Table 3: Continued... } \\
\hline X2d2 & 4.022 & $\mathbf{1 8}$ & Decision making \\
\hline X3b2 & 4.000 & $\mathbf{1 9}$ & Bad communication and coordination \\
\hline X4b1 & 3.978 & $\mathbf{2 0}$ & Drawing information is in PDF format \\
\hline X1d2 & 3.956 & $\mathbf{2 1}$ & Soil condition \\
\hline X2b1 & 3.911 & $\mathbf{2 2}$ & Late progress payment by owner \\
\hline X2a1 & 3.867 & $\mathbf{2 3}$ & Issuance of Purchase Order \\
\hline X3d2 & 3.844 & $\mathbf{2 4}$ & Unfinished work \\
\hline X3d3 & 3.844 & $\mathbf{2 5}$ & Unclear scope of work \\
\hline X4d3 & 3.844 & $\mathbf{2 6}$ & Damage of heavy equipment \\
\hline X1b4 & 3.778 & $\mathbf{2 7}$ & Delay in production of drawings \& tender documents \\
\hline X6b1 & 3.756 & $\mathbf{2 8}$ & Unclear scope of work \\
\hline X1a3 & 3.622 & $\mathbf{2 9}$ & Changes in regulation \\
\hline X2d3 & 3.622 & $\mathbf{3 0}$ & Variation order price \\
\hline X4d2 & 3.622 & $\mathbf{3 1}$ & Material delivery time \\
\hline X2a2 & 3.600 & $\mathbf{3 2}$ & Feasibility study \\
\hline X4a1 & 3.600 & $\mathbf{3 3}$ & Consultant presentation \\
\hline X2c2 & 3.556 & $\mathbf{3 4}$ & Design and drawing changes \\
\hline X1c1 & 3.511 & $\mathbf{3 5}$ & Determination of the long tender schedule \\
\hline X4a2 & 3.422 & $\mathbf{3 6}$ & The process of tendering and the implementation of new site \\
\hline X1c2 & 3.378 & $\mathbf{3 7}$ & Many stages of clarification \\
\hline X1d4 & 3.200 & $\mathbf{3 8}$ & Regional regulations \\
\hline X1b1 & 3.178 & $\mathbf{3 9}$ & Differences in idealism with foreign consultants \\
\hline X3c2 & 3.156 & $\mathbf{4 0}$ & Tenders are carried out separately per scope of work \\
\hline X1a1 & 3.133 & $\mathbf{4 1}$ & Building permit data is different from site conditions \\
\hline X3a1 & 3.133 & $\mathbf{4 2}$ & Incomplete As-built drawings \\
\hline X3b1 & 3.133 & $\mathbf{4 3}$ & Coordination meetings between consultants \\
\hline X3d1 & 3.111 & $\mathbf{4 4}$ & Additional work due to damage of existing buildings \\
\hline X1a2 & 3.022 & $\mathbf{4 5}$ & Lack of open spaces \\
\hline & & & \\
\hline
\end{tabular}

\section{Risk Response}

According to Flanagan and Norman (1993) there are 4 types of response to risk, namely risk retention, risk reduction, risk transfer, and risk avoidance. If the risks that arise as a result of an activity have been identified, according to it, then actions are taken to reduce the risks that arise. After conducting surveys and interviews with experts, the response to risk can be seen in Table 4.

Table 4. Risk Response

\begin{tabular}{|c|c|c|c|c|c|}
\hline & \multirow[b]{2}{*}{ Var } & \multirow{2}{*}{\multicolumn{4}{|c|}{ Resnonse }} \\
\hline & & & Risk & Category & Response \\
\hline & $\mathrm{X} 1 \mathrm{a}$ & X1a1 & 0,28 & High & Reduction \\
\hline & & $\mathrm{X} 1 \mathrm{a} 2$ & 0,10 & Medium & Retention \\
\hline \multirow{11}{*}{ PRE DESIGN (Xa) } & & $\mathrm{X} 1 \mathrm{a} 3$ & 0,20 & High & Retention \\
\hline & $\mathrm{X} 2 \mathrm{a}$ & $\mathrm{X} 2 \mathrm{a} 1$ & 0,28 & High & Transfer \\
\hline & & $\mathrm{X} 2 \mathrm{a} 2$ & 0,28 & High & Transfer \\
\hline & X3a & X3a1 & 0,10 & Medium & Reduction \\
\hline & & $\mathrm{X} 3 \mathrm{a} 2$ & 0,28 & High & Reduction \\
\hline & $\mathrm{X} 4 \mathrm{a}$ & $\mathrm{X} 4 \mathrm{a} 1$ & 0,10 & Medium & Retention \\
\hline & & $\mathrm{X} 4 \mathrm{a} 2$ & 0,10 & Medium & Retention \\
\hline & $\mathrm{X} 1 \mathrm{~b}$ & X1b1 & 0,10 & Medium & Retention \\
\hline & & $\mathrm{X} 1 \mathrm{~b} 2$ & 0,14 & Medium & Reduction \\
\hline & & $\mathrm{X} 1 \mathrm{~b} 3$ & 0,56 & Very High & Reduction \\
\hline & & $\mathrm{X} 1 \mathrm{~b} 4$ & 0,28 & High & Reduction \\
\hline \multirow[t]{10}{*}{ DESIGN (Xb) } & $\mathrm{X} 2 \mathrm{~b}$ & $\mathrm{X} 2 \mathrm{~b} 1$ & 0,56 & Very High & Transfer \\
\hline & & $\mathrm{X} 2 \mathrm{~b} 2$ & 0,72 & Very High & Transfer \\
\hline & & $\mathrm{X} 2 \mathrm{~b} 3$ & 0,28 & High & Retention \\
\hline & & $\mathrm{X} 2 \mathrm{~b} 4$ & 0,36 & High & Transfer \\
\hline & X3b & $\mathrm{X} 3 \mathrm{~b} 1$ & 0,20 & High & Retention \\
\hline & & $\mathrm{X} 3 \mathrm{~b} 2$ & 0,56 & Very High & Avoidance \\
\hline & $\mathrm{X} 4 \mathrm{~b}$ & $\mathrm{X} 4 \mathrm{~b} 1$ & 0,28 & High & Transfer \\
\hline & & $\mathrm{X} 4 \mathrm{~b} 2$ & 0,24 & Very High & Retention \\
\hline & $\mathrm{X} 5 \mathrm{~b}$ & $\mathrm{X} 5 \mathrm{~b} 1$ & 0,24 & Very High & Retention \\
\hline & X6b & X6b1 & 0,28 & High & Avoidance \\
\hline \multirow[t]{6}{*}{ TENDER (Xc) } & $\mathrm{X} 1 \mathrm{c}$ & $\mathrm{X} 1 \mathrm{c} 1$ & 0,28 & Very High & Transfer \\
\hline & & $\mathrm{X} 1 \mathrm{c} 2$ & 0,28 & Very High & Retention \\
\hline & $\mathrm{X} 2 \mathrm{c}$ & $\mathrm{X} 2 \mathrm{c} 1$ & 0,24 & High & Retention \\
\hline & & $\mathrm{X} 2 \mathrm{c} 2$ & 0,28 & High & Retention \\
\hline & $\mathrm{X} 3 \mathrm{c}$ & $\mathrm{X} 3 \mathrm{c} 1$ & 0,28 & High & Reduction \\
\hline & & $\mathrm{X} 3 \mathrm{c} 2$ & 0,24 & Very High & Transfer \\
\hline
\end{tabular}


Anastasia Erlita et.al. Risk management of time overrun in multiple phases of construction: consultant perspective.

\begin{tabular}{|c|c|c|c|c|c|}
\hline \multicolumn{6}{|c|}{ Table 4: Continued... } \\
\hline \multirow[t]{16}{*}{ KONSTRUKSI (Xd) } & X1d & X1d1 & 0,28 & High & Reduction \\
\hline & & $\mathrm{X} 1 \mathrm{~d} 2$ & 0,24 & Very High & Retention \\
\hline & & $\mathrm{X} 1 \mathrm{~d} 3$ & 0,28 & High & Reduction \\
\hline & & $\mathrm{X} 1 \mathrm{~d} 4$ & 0,10 & Medium & Reduction \\
\hline & $\mathrm{X} 2 \mathrm{~d}$ & $\mathrm{X} 2 \mathrm{~d} 1$ & 0,28 & High & Transfer \\
\hline & & $\mathrm{X} 2 \mathrm{~d} 2$ & 0,36 & High & Transfer \\
\hline & & $\mathrm{X} 2 \mathrm{~d} 3$ & 0,28 & High & Transfer \\
\hline & $\mathrm{X} 3 \mathrm{~d}$ & $\mathrm{X} 3 \mathrm{~d} 1$ & 0,20 & High & Retention \\
\hline & & $\mathrm{X} 3 \mathrm{~d} 2$ & 0,28 & High & Reduction \\
\hline & & $\mathrm{X} 3 \mathrm{~d} 3$ & 0,28 & High & Avoidance \\
\hline & $\mathrm{X} 4 \mathrm{~d}$ & $\mathrm{X} 4 \mathrm{~d} 1$ & 0,14 & Medium & Reduction \\
\hline & & $\mathrm{X} 4 \mathrm{~d} 2$ & 0,20 & High & Reduction \\
\hline & & $\mathrm{X} 4 \mathrm{~d} 3$ & 0,28 & High & Reduction \\
\hline & X5d & $\mathrm{X} 5 \mathrm{~d} 1$ & 0,56 & Very High & Retention \\
\hline & & $\mathrm{X} 5 \mathrm{~d} 2$ & 0,72 & Very High & Reduction \\
\hline & & $\mathrm{X} 5 \mathrm{~d} 3$ & 0,28 & High & Avoidance \\
\hline
\end{tabular}

\section{CONCLUSION}

This study found 45 factors causing delays in all phases which were divided into 7 factors from the pre-planning phase, 14 factors from the planning phase, 6 factors from the tender phase and 16 factors from the construction or implementation phase. Recommendations for risk management with 4 options: retained, reduced, transferred or avoided by looking at the magnitude of the risk of each factor.

In the RII, which is sorted by all phases, it is found that the top 5 causes of delays in this project are found. The first reason for the delay is $\mathrm{X} 3 \mathrm{a} 2$, which has a value of 4.578 , which is a change in design idea. The second value of $\mathrm{X} 3 \mathrm{c} 1$ is 4.533 , which is the the technical data of new machines appearing. The third row is X2b4, the value is 4.467, waiting for owner's decision. The fourth place is the variable X1b3 Machine technical data appears after tender, with a value of 4.422 , and the fifth place is the difference between local regulations and foreign regulations, with a value of 4.378 .

\section{Acknowledgement: None}

\section{Conflict of Interest: None}

\section{Source of Funding: None}

\section{REFERENCES}

1. Badreddine, A. et al. (2014). A new multiobjectives approach to implement preventive and protective barriers in bow tie diagram. Journal of Loss Prevention in the
Process Industries. Elsevier Ltd, 32, pp. 238-253. doi: 10.1016/j.jlp.2014.09.012.

2. Flanagan, R. and Norman, G. (1993). Risk Management and Construction', Blackwell Science, London.

3. Gündüz, M., Nielsen, Y. and Özdemir, M. (2013). Quantification of delay factors using the relative importance index method for construction projects in Turkey. Journal of Management in Engineering, 29(2). pp. 133-139. doi: 10.1061/(ASCE)ME.19435479.0000129.

4. Hasan, R. et al. (2014). An Investigation into the Delays in Road Projects in Bahrain. Int. J.Res. Eng. Sci. pp. 38-47.

5. Ibironke, O. T. et al. (2013). Analysis of non-excusable delay factors influencing contractors' performance in Lagos State, Nigeria. Journal of Construction in Developing Countries. 18(1), pp. 53-72.

6. Kikwasi, G. (2013). Causes and Effects of Delays and Disruptions in Construction Projects in Tanzania. Australasian Journal of Construction Economics and Building Conference Series. 1(2), p. 52. doi: 10.5130/ajceb-cs.v1i2.3166.

7. Le-Hoai, L., Lee, Y. D. and Lee, J. Y. (2008). Delay and cost overruns in Vietnam large construction projects: A comparison with other selected countries. KSCE Journal of Civil Engineering. 12(6), pp. 367-377. doi: 10.1007/s12205-008-0367-7.Fsu

8. Lo, T. Y., Fung, I. W. H. and Tung, K. C. F. (2006). Construction delays in Hong Kong civil engineering projects. Journal of Construction Engineering and Management, 132(6). pp. 636-649. doi: 10.1061/(ASCE)07339364(2006)132:6(636).

9. Pai, S.K., and Bharath, J. (2013). Analysis of Critical Causes of Delays in Indian 
Infrastructure Projects. International journal of innovative research and development. pp. 251-263.

10. Project Management Institute. (2017). A guide to the project management body of knowledge (PMBOK guide $6^{\text {th }}$ edition). Newtown Square, Pa, Project Management Institute.

11. Sudirman, W. B. and Hardjomuljadi, S. (2011). Project Risk Management in Hydropower Plant Projects: a Case Study from the State-owned Electricity Company of Indonesia. Journal of Infrastructure Development. pp. 1-16. doi: 10.2139/ssrn.1853943

12. Susetyo, B. and Utami, T. B. (2017). Bidding Cost Evaluation with Fuzzy Methods on Building Project in Jakarta. AIP Conference Proceedings. pp. 1-6. doi : $10.1063 / 1.5011573$

13. Sweis, G. J. (2013). Factors Affecting Time Overruns in Public Construction Projects: The Case of Jordan. International Journal of Business and Management, 8(23). doi: 10.5539/ijbm.v8n23p120.

14. Tafazzoli, M. and Shrestha, P. (2017). Factor analysis of construction delays in the U.S. construction industry. International Conference on Sustainable Infrastructure
2017: Methodology - Proceedings of the International Conference on Sustainable Infrastructure 2017. pp. 111-122. doi: 10.1061/9780784481196.011.

15. Tumi, S. A. H., Omran, A. and Pakir, A. H. K. (2009). Causes of Delay in Construction Industry in Libya. The International Conference on Economics and Administration, (November). pp. 265-272.

16. Ullah, I. (2020). Assessment of Critical Factors Responsible for Cost and Time Overruns in Pre Construction Planning Phase of Construction Projects Assessment of Critical Factors Responsible for Cost and Time Overruns in Pre Construction Planning Phase of Construction Proj (December 2019). doi: 10.7176/CER/11-1207.

17. Umum, M. P. et al. (2007). Pelatihan ahli manajemen konstruksi. Departemen pekerjaan umum. pp. II-4

How to cite this article: Erlita A, Amin M, Bintoro BPK. Risk management of time overrun in multiple phases of construction: consultant perspective. International Journal of Research and Review. 2021; 8(7): 311-319. DOI: https:// doi.org/10.52403/ijrr.20210743 